\title{
14. POSSIBLE INDICATORS OF DEGREE OF RADIOLARIA DISSOLUTION IN CALCAREOUS SEDIMENTS OF THE ONTONG-JAVA PLATEAU
}

\author{
B.K. Holdsworth and B.M. Harker, The University, Keele, Staffordshire, England
}

\section{INTRODUCTION}

While carrying out conventional paleontologic studies of Cenozoic Radiolaria in Leg 30 samples, we attempted to obtain some information regarding fluctuations in degree of dissolution of Radiolaria assemblages in two late Eocene through Pleistocene columns of calcareous sediments. The approach was simplistic and the data obtained are incomplete and difficult to interpret. Nevertheless, as little comparable published information appears to exist, it seems worthwhile to briefly report our preliminary results and inferences.

\section{BACKGROUND OF THE INVESTIGATION}

The columns investigated are those at Sites 288 and 289 , both lying within the general area of the OntongJava Plateau, but revealing some significant contrasts in stratigraphy. Site 289 , which was continuously cored to the Cretaceous basement, lies within the main essentially level plateau area at $00^{\circ} 29.92^{\prime} \mathrm{S}, 158^{\circ} 30.69^{\prime} \mathrm{E}$ beneath 2206 meters of water. Site 288 lies upon the eastern flank of the plateau at $05^{\circ} 58.35^{\prime} \mathrm{S}, 161^{\circ} 49.53^{\prime} \mathrm{E}$, and the discontinuously cored column is beneath 3000 meters of water.

At an early stage in the examination of Cenozoic foram-nanno ooze, chalk, and limestone from Holes 288 and $288 \mathrm{~A}$ it was noted that many samples contained apparently unusually high percentages of collosphaerid Radiolaria and/or Spyrida, the latter usually forms with simple or very simple skeletons (see Plate 1). As it had previously been suggested to the senior author by W.R. Riedel that abnormally high collosphaerid percentages probably indicate a degree of selective solution of Radiolaria assemblages, it appeared possible that the spyrid concentrations have a similar significance. We decided, therefore, to compare the collosphaerid and/or spyrid percentages in samples from the discontinuously cored $288-288 \mathrm{~A}$ column with those of samples of comparable age from the adjacent, completely cored and lithologically similar 289 succession in an attempt to discover whether real differences in abundance of these two very broad groups do exist between contemporaneous, lithologically similar sediments accumulated at essentially similar latitude.

\section{METHOD}

Abundances of collosphaerids and spyrids were determined in slides of the $>63 \mu \mathrm{m}$ Radiolaria fraction prepared in the standard way. Estimates were made by counting all radiolarians in a microscope field at $60 \times$ magnification, separately counting the spyrids and collosphaerids, and calculating spyrid and collosphaerid abundances as percentages of the total. The final figures for any one sample (Table 1) are averages of determinations in at least five separate fields. Broken specimens were ignored unless half the skeleton was present. The final figures are unlikely to be accurate, but as all determinations were made by a single observer (B.M.H.) over a short period, a fair degree of consistency was probably achieved.

TABLE 1

Percentage Abundances of Spyrid and and Collosphaerid Radiolaria in Hole 289

\begin{tabular}{|c|c|c|c|}
\hline Sample & Spyrids & Collosphaerids & Total \\
\hline $1, \mathrm{CC}$ & 3 & 2 & 5 \\
\hline $2, \mathrm{CC}$ & 3 & Trace & 3 \\
\hline $3, \mathrm{CC}$ & 6 & Trace & 6 \\
\hline $4, \mathrm{CC}$ & 8 & Trace & 8 \\
\hline $5, \mathrm{CC}$ & 3 & 2 & 5 \\
\hline $6, \mathrm{CC}$ & 3 & 2 & 5 \\
\hline 7, CC & 6 & Trace & 6 \\
\hline $8, \mathrm{CC}$ & 8.5 & 2 & 10.5 \\
\hline $9, \mathrm{CC}$ & 5 & 3 & 8 \\
\hline $10, \mathrm{CC}$ & 16 & Trace & 16 \\
\hline $11, \mathrm{CC}$ & 21 & Trace & 21 \\
\hline $12, \mathrm{CC}$ & 7 & Trace & 7 \\
\hline $13, \mathrm{CC}$ & 10 & 2 & 12 \\
\hline $14, \mathrm{CC}$ & 14 & 13 & 27 \\
\hline $15, \mathrm{CC}$ & 10 & 3 & 13 \\
\hline $16, \mathrm{CC}$ & 5 & 24 & 29 \\
\hline $17, \mathrm{CC}$ & 7 & 5 & 12 \\
\hline $18-3$ & 6 & 7 & 13 \\
\hline $18, \mathrm{CC}$ & 7 & 19 & 26 \\
\hline $19-3$ & 3 & 9 & 12 \\
\hline $19, \mathrm{CC}$ & 10 & 12 & 22 \\
\hline $20-4$ & 2.5 & 12 & 14.5 \\
\hline $20, \mathrm{CC}$ & 12 & 18 & 30 \\
\hline $21-2$ & 2 & 18 & 20 \\
\hline $21, \mathrm{CC}$ & 10 & 25 & 35 \\
\hline $22-3$ & 1 & 25 & 26 \\
\hline $22, \mathrm{CC}$ & 10 & 11 & 21 \\
\hline $23-4$ & 4 & 30 & 34 \\
\hline $23, \mathrm{CC}$ & 14 & 34 & 48 \\
\hline $24-4$ & 2 & 55 & 57 \\
\hline $24, \mathrm{CC}$ & 15 & 20 & 35 \\
\hline $25-3$ & 7 & 19 & 26 \\
\hline $25, \mathrm{CC}$ & 13 & 11 & 24 \\
\hline $26-4$ & 7 & 6 & 13 \\
\hline $26, \mathrm{CC}$ & 13 & 6 & 19 \\
\hline $27, \mathrm{CC}$ & 11 & 1.5 & 12.5 \\
\hline $28-4$ & 3 & 9 & 12.0 \\
\hline $28, \mathrm{CC}$ & 14.5 & 3 & 17.5 \\
\hline $29, \mathrm{CC}$ & 12.5 & 7 & 19.5 \\
\hline $30, \mathrm{CC}$ & 15 & 5 & 20 \\
\hline $31-4$ & 9 & 3 & 12 \\
\hline $31, \mathrm{CC}$ & 11.5 & 2.5 & 14 \\
\hline $32-3$ & 4 & 1 & 5 \\
\hline $32, \mathrm{CC}$ & 7 & 3 & 10 \\
\hline $33-4$ & 6 & 6 & 12 \\
\hline $33, \mathrm{CC}$ & 9 & 11 & 20 \\
\hline $34-4$ & 5.5 & 4.5 & 10 \\
\hline $34, \mathrm{CC}$ & 24 & 12 & 36 \\
\hline
\end{tabular}


TABLE 1 - Continued

\begin{tabular}{|c|c|c|c|}
\hline Sample & Spyrids & Collosphaerids & Total \\
\hline $35-3$ & 3 & 5 & 8 \\
\hline $35, \mathrm{CC}$ & 9 & 22 & 21 \\
\hline $36-4$ & 1.5 & 1 & 2.5 \\
\hline $36, \mathrm{CC}$ & 18 & 3 & 21 \\
\hline $37-4$ & 5 & Trace & 5 \\
\hline $37, \mathrm{CC}$ & 17 & 2 & 19 \\
\hline $38-3$ & 7 & Trace & 7 \\
\hline $38-5$ & 2 & Trace & 2 \\
\hline $38, \mathrm{CC}$ & 10 & Trace & 10 \\
\hline $39-3$ & 8 & Trace & 8 \\
\hline $39, \mathrm{CC}$ & 18 & Trace & 18 \\
\hline $40-3$ & 20 & Trace & 20 \\
\hline $40-5$ & 13 & Trace & 13 \\
\hline $40, \mathrm{CC}$ & 19 & Trace & 19 \\
\hline $41-1$ & 15 & Trace & 15 \\
\hline $41, \mathrm{CC}$ & 30 & 3.5 & 33.5 \\
\hline $42-4$ & 18 & Trace & 18 \\
\hline $42, \mathrm{CC}$ & 29 & 1 & 30 \\
\hline $43, \mathrm{CC}$ & 15 & 16 & 31 \\
\hline $44-3$ & 13 & 3 & 16 \\
\hline $44-5$ & 13 & 17 & 30 \\
\hline $44, \mathrm{CC}$ & 15 & 28 & 43 \\
\hline $45-5$ & 29 & 10 & 39 \\
\hline $45, \mathrm{CC}$ & 19 & 10 & 29 \\
\hline $46, \mathrm{CC}$ & 23 & 9 & 32 \\
\hline $47-3$ & 37 & 3 & 40 \\
\hline $47-5$ & 30 & 5 & 35 \\
\hline $47, \mathrm{CC}$ & 26 & 13 & 39 \\
\hline $48-3$ & 16 & 3 & 19 \\
\hline $48-5$ & 10 & Trace & 10 \\
\hline $48, \mathrm{CC}$ & 25 & 8 & 33 \\
\hline $49-3$ & 12 & 3 & 15 \\
\hline $49-5$ & 16 & Trace & 16 \\
\hline $49, \mathrm{CC}$ & 28 & Trace & 28 \\
\hline $50-3$ & 15 & Trace & 15 \\
\hline $50, \mathrm{CC}$ & 30 & Trace & 30 \\
\hline $51-3$ & 13 & Trace & 13 \\
\hline $51-5$ & 14 & Trace & 14 \\
\hline $51, \mathrm{CC}$ & 25 & Trace & 25 \\
\hline $52, \mathrm{CC}$ & 21 & Trace & 21 \\
\hline $53-3$ & 21 & 2 & 23 \\
\hline $54-3$ & 19 & Trace & 19 \\
\hline $54, \mathrm{CC}$ & 19 & Trace & 19 \\
\hline $55-3$ & 7 & Trace & 7 \\
\hline $55, \mathrm{CC}$ & 16 & Trace & 16 \\
\hline $56-2$ & 11 & Trace & 11 \\
\hline $56, \mathrm{CC}$ & 14 & Trace & 14 \\
\hline $57-3$ & 5 & Trace & 5 \\
\hline $57, \mathrm{CC}$ & 16 & Trace & 16 \\
\hline $58-4$ & 20 & Trace & 20 \\
\hline $58, \mathrm{CC}$ & 20 & Trace & 20 \\
\hline $59-1$ & 13 & Trace & 13 \\
\hline $59, \mathrm{CC}$ & 18 & Trace & 18 \\
\hline $60-2$ & 20 & - & 20 \\
\hline $60-4$ & 16 & Trace & 16 \\
\hline $60, \mathrm{CC}$ & 21 & Trace & 21 \\
\hline $61-4$ & 24 & Trace & 24 \\
\hline $61, \mathrm{CC}$ & 20 & Trace & 20 \\
\hline $62-1$ & 23 & Trace & 23 \\
\hline $62, \mathrm{CC}$ & 27 & Trace & 27 \\
\hline $63-1$ & 45 & - & 45 \\
\hline $63, \mathrm{CC}$ & 36 & Trace & 36 \\
\hline $64, \mathrm{CC}$ & 40 & Trace & 40 \\
\hline $65-2$ & 28 & Trace & 28 \\
\hline $65, \mathrm{CC}$ & 43 & Trace & 43 \\
\hline $66-2$ & 35 & - & 35 \\
\hline $66, \mathrm{CC}$ & 33 & Trace & 33 \\
\hline $67-3$ & 54 & - & 54 \\
\hline $67, \mathrm{CC}$ & 48 & Trace & 48 \\
\hline $68, \mathrm{CC}$ & 38 & - & 38 \\
\hline
\end{tabular}

TABLE 1 - Continued

\begin{tabular}{|c|c|c|c|}
\hline Sample & Spyrids & Collosphaerids & Total \\
\hline $69-3$ & 38 & - & 38 \\
\hline $69, \mathrm{CC}$ & 50 & Trace & 50 \\
\hline $70-3$ & 55 & - & 55 \\
\hline $70, \mathrm{CC}$ & 38 & - & 38 \\
\hline $71-2$ & 54 & Trace & 54 \\
\hline $71-5$ & 61 & Trace & 61 \\
\hline $71, \mathrm{CC}$ & 53 & - & 53 \\
\hline $72-3$ & 53 & - & 53 \\
\hline $72, \mathrm{CC}$ & 56 & - & 56 \\
\hline $73-3$ & 57 & Trace & 57 \\
\hline $73, \mathrm{CC}$ & 51 & - & 51 \\
\hline $74-1$ & 44 & - & 44 \\
\hline $74-3$ & 57 & - & 57 \\
\hline $74-5$ & 64 & - & 64 \\
\hline $75, \mathrm{CC}$ & 52 & - & 52 \\
\hline $76-3$ & 66 & - & 66 \\
\hline $76, \mathrm{CC}$ & 56 & - & 56 \\
\hline $77-1$ & 56 & Trace & 56 \\
\hline $77, \mathrm{CC}$ & 46 & Trace & 46 \\
\hline $78-1$ & 67 & - & 67 \\
\hline $78, \mathrm{CC}$ & 44 & - & 44 \\
\hline $79-1$ & 43 & - & 43 \\
\hline $79, \mathrm{CC}$ & 43 & - & 43 \\
\hline $80-2$ & 43 & - & 43 \\
\hline $80, \mathrm{CC}$ & 44 & - & 44 \\
\hline $81-2$ & 37 & - & 37 \\
\hline $81, \mathrm{CC}$ & 30 & - & 30 \\
\hline $82-2$ & 44 & - & 44 \\
\hline $82, \mathrm{CC}$ & 42 & - & 42 \\
\hline $83-2$ & 48 & - & 48 \\
\hline $83, \mathrm{CC}$ & 50 & - & 50 \\
\hline $84, \mathrm{CC}$ & 49 & - & 49 \\
\hline $85, \mathrm{CC}$ & 34 & - & 34 \\
\hline $86-2$ & 66 & - & 66 \\
\hline $86-4$ & 55 & - & 55 \\
\hline $86, \mathrm{CC}$ & 63 & - & 63 \\
\hline $87, \mathrm{CC}$ & 35 & - & 35 \\
\hline $88, \mathrm{CC}$ & 35 & - & 35 \\
\hline $89, \mathrm{CC}$ & 34 & - & 34. \\
\hline $90, \mathrm{CC}$ & 36 & - & $36^{\circ}$ \\
\hline $91, \mathrm{CC}$ & 22.5 & - & 22.5 \\
\hline $92-1$ & 42 & - & 42 \\
\hline $92, \mathrm{CC}$ & 38 & - & 38 \\
\hline $93, \mathrm{CC}$ & 30 & - & 30 \\
\hline $94-2$ & 48 & - & 48 \\
\hline $94-4$ & 50 & - & 50 \\
\hline $94, \mathrm{CC}$ & 25 & - & 25 \\
\hline $95-1$ & 23 & - & 23 \\
\hline $95, \mathrm{CC}$ & 24 & - & 24 \\
\hline $96-1$ & 22 & - & 22 \\
\hline $96, \mathrm{CC}$ & 22 & - & 22 \\
\hline $98, \mathrm{CC}$ & 20 & - & 20 \\
\hline $99, \mathrm{CC}$ & 23 & - & 23 \\
\hline $100-1$ & 34 & - & 34 \\
\hline $100, \mathrm{CC}$ & 17.5 & - & 17.5 \\
\hline $101-2$ & 32 & - & 32 \\
\hline $101, \mathrm{CC}$ & 32 & - & 32 \\
\hline $102, \mathrm{CC}$ & 19 & - & 19 \\
\hline $103, \mathrm{CC}$ & 32 & - & 32 \\
\hline $104-1$ & 30 & - & 30 \\
\hline $105, \mathrm{CC}$ & 18 & - & 18 \\
\hline $106, \mathrm{CC}$ & 16 & - & 16 \\
\hline $107, \mathrm{CC}$ & 10 & - & 10 \\
\hline
\end{tabular}

Due to the short time available for the study, it was necessary to consider the Spyrida as a whole, though the most significant abundance fluctuations are likely to be those of the smaller forms with relatively robust, simple 
lattices which clearly predominate in the OligoceneMiocene samples from Site 288.

Estimates were made for the majority of Site 289 samples prepared in the course of the conventional paleontologic study and the 184 sets of determinations used to construct a "profile" showing collosphaerid and/or spyrid totals in this hole from late Eocene through Pleistocene (Figure 1). Radiolarians in Cores 108,109 , and 110 are either absent or so scarce as to prohibit determinations. Below Core 110 radiolarians are virtually absent in the hole. Determinations on 28 288-288A samples were made (Table 2). Results are plotted on Figure 1 at levels appropriate to the apparent ages of the samples. Where precise correlation of a core with 289 appears possible, the correlation level is indicated by an arrow. Where only limits can be given for positioning of a $288-288 \mathrm{~A}$ sample relative to 289 , these limits are indicated by dotted lines.

\section{DISCUSSION OF COLLOSPHAERID-SPYRID RESULTS}

Measurable percentages of collosphaerids at Site 289 were not found below latest early Miocene Core 53, though they are first detectable in late Oligocene Core 81. In Hole 288-288A the level of first appearance of measurable percentages must occur between latest early Miocene and mid-middle Miocene.

Wide fluctuation in collosphaerid and/or spyrid totals between closely spaced samples is evident at Site 289 (Figure 1), but certain segments of the column do seem to show persistent relative enrichment.

Clearly apparent from Figure 1 is the marked enrichment of Hole 288-288A middle Miocene through Pliocene sediments in collosphaerids and/or spyrids relative to Site 289. Values for Oligocene samples show less difference between holes, and in two instances values are actually lower in Hole 288A than at Site 289.

As Sites 288 and 289 are so closely adjacent, it is difficult to believe that differences in make-up of contemporaneous living Mio-Pliocene Radiolaria assemblages could have been so different as to produce the observed contrasts in the fossil assemblages. Clearly, Mio-Pliocene spyrids and/or collosphaerids have been preferentially concentrated at Site 288 . The only reasonable explanation seems to be that this is the result of a greater intensity of dissolution of the 288 assemblages and that the collosphaerids and spyrids were relatively resistant.

Presuming that differences in collosphaerid and/or spyrid abundance do indicate differences in opal solution intensity from site to site, it seems possible that vertical variations of abundance indicate levels of more or less severe solution in a single borehole. The absolute abundance resulting from a particular intensity of opal solution will vary according to the age-and consequent initial make-up - of the assemblage affected. But rises and falls of abundance through short segments, apparent to a certain extent in the Site 289 profile, may give an indication of relative intensity of solution.

\section{DETECTION OF MAXIMUM SOLUTION LEVELS AT SITE 289}

Pronounced peaks of spyrid and/or collosphaerid abundance cannot be assumed to define the levels of maximum opal solution in a borehole. The result of the most intense solution will be a total disappearance of Radiolaria. No such barren levels were encountered at Site 289 above 107, CC, but barren or very sparse levels are known in the contemporaneous 288 column (Table 1). Nor can it be assumed that at solution intensities intermediate between those competent to increase the spyrid and/or collosphaerid count and those resulting in total loss, spyrids and collosphaerids will continue to be preferentially concentrated. (Our data can, in fact, be construed to show that collosphaerids concentrate only at relatively low solution intensities.)

As solution intensity rises, however, other effects might be expected. The proportion of Radiolaria in the total sediment should fall; rarer and/or more solutionprone taxa should become undetectable or very sparse, and poorly preserved; and partly dissolved individuals should become more noticeable.

We have not been able to measure these effects quantitatively in this rapid reconnaissance, and poor individual preservation, due to its very varied manifestations, is probably not truly quantifiable. Nevertheless, some indication of fluctuations in all three parameters can be given.

Regarding total abundance, we have classified the bulk returns of Radiolaria from all processed Site 289 section samples as "good," "low," or "very low." Low and very low returns are recorded in Figure 1. Samples from the uppermost 11 cores were not of full size and returns cannot be compared validly with those of lower samples, but abundance appears to be consistently low throughout the later Pliocene and Pleistocene. It has also been possible to extract from the paleontologic notes the comparatively few records of "poor preservation" and "restricted fauna." Such records were made where serious doubt existed as to whether preservation of specimens and/or diversity were adequate to allow a reliable tabulation of important biostratigraphic taxa. They were made before the results of the spyridcollosphaerid counts were known, and though probably not comprehensive, at least they were not governed by preconceptions regarding solution intensity based upon the spyrid and/or collosphaerid profile. These records are also included in Figure 1.

The data we have on the four parameters considered, taken together, reveal a moderately convincing pattern. Seventeen of 22 "very low" return records lie within or adjacent to highs in the spyrid and/or collosphaerid profile, as do 10 out of 14 records of "restricted fauna" and 12 out of 15 records of "poor preservation." Three segments of the column show particularly convincing associations of the four suggested solution indicators: Cores 289-19 through 289-24, 289-86, and 289-92 through 289-94.

Of these, the late Miocene segment, Cores 289-19 through $289-24$, is distinct in showing very low returns, poor preservation, and restricted faunas slightly above, rather than coincident with, the spyrid and/or collosphaerid peak. The peak is unusual, however, in being largely due to collosphaerids (Table 1). Its rapid decay below what appears to be the most intensely dissolved levels could indicate that collosphaerids are significantly solution-resistant only at relatively low solution 
B. K. HOLDSWORTH, B. M. HARKER
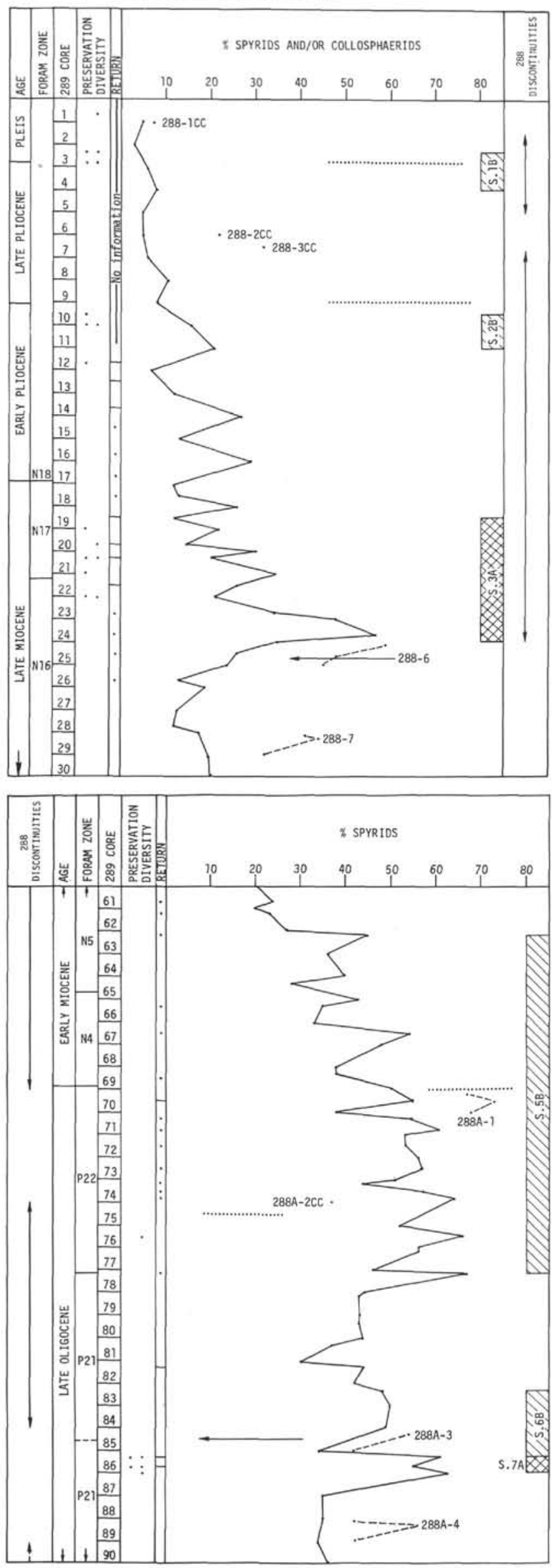
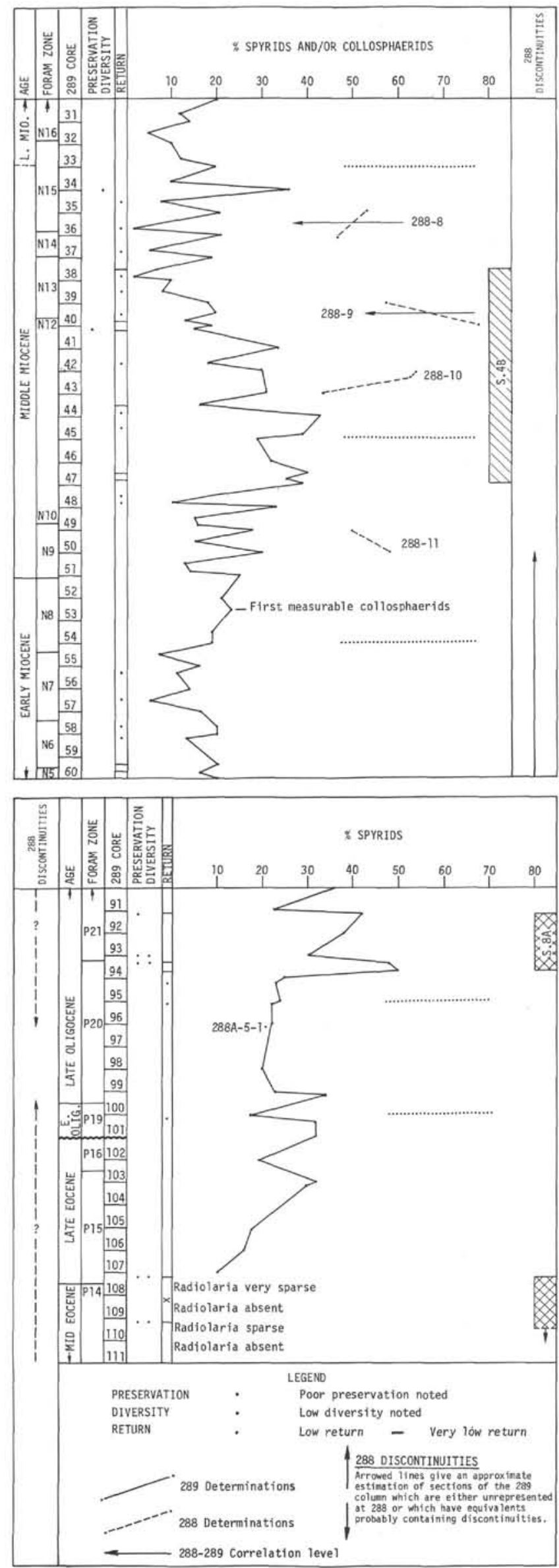

Figure 1. Spyrid and/or collosphaerid percentages at 289 and 288. 
TABLE 2

Percentage Abundances of Spyrid and Collosphaerid Radiolaria in Holes 288 and 288A

\begin{tabular}{|c|c|c|c|}
\hline Sample & Spyrids & Collosphaerids & Total \\
\hline \multicolumn{4}{|c|}{ Hole 288} \\
\hline $1, \mathrm{CC}$ & 6 & 2 & 8 \\
\hline $2, \mathrm{CC}$ & 10 & 12 & 22 \\
\hline $3, \mathrm{CC}$ & 12 & 20 & 32 \\
\hline $4-1$ & \multicolumn{3}{|c|}{$\begin{array}{l}\text { Too few Radiolaria } \\
\text { for determination }\end{array}$} \\
\hline $4, \mathrm{CC}$ & \multicolumn{3}{|c|}{$\begin{array}{l}\text { Too few Radiolaria } \\
\text { for determination }\end{array}$} \\
\hline $5, \mathrm{CC}$ & \multicolumn{3}{|c|}{$\begin{array}{l}\text { Too few Radiolaria } \\
\text { for determination }\end{array}$} \\
\hline $6-1$ & 23 & 36 & 59 \\
\hline $6-4$ & 23 & 25 & 48 \\
\hline $6, \mathrm{CC}$ & 19 & 26 & 45 \\
\hline $7-1$ & 25 & 16 & 41 \\
\hline $7-2$ & 26 & 18 & 44 \\
\hline $7, \mathrm{CC}$ & 20 & 12 & 32 \\
\hline $8-1$ & 34 & 22 & 56 \\
\hline $8, \mathrm{CC}$ & 46 & 1 & 47 \\
\hline $9, \mathrm{CC}$ & 47 & 31 & 78 \\
\hline $10-1$ & 61 & 3 & 64 \\
\hline $10-2$ & 58 & 7 & 65 \\
\hline $10, \mathrm{CC}$ & 39 & 4.5 & 43.5 \\
\hline $11-1$ & 50 & Trace & 50 \\
\hline $11, \mathrm{CC}$ & 58 & Trace & 58 \\
\hline
\end{tabular}

Hole 288A

\begin{tabular}{|c|c|c|c|}
\hline $1-1$ & 67 & - & 67 \\
\hline $1-3$ & 73 & - & 73 \\
\hline $1, \mathrm{CC}$ & 68 & - & 68 \\
\hline $2, \mathrm{CC}$ & 37 & - & 37 \\
\hline $3-1$ & \multirow{2}{*}{\multicolumn{3}{|c|}{$\begin{array}{l}\text { No Radiolaria } \\
\text { Too few Radiolaria } \\
\text { for determination }\end{array}$}} \\
\hline $3-2$ & & & \\
\hline $3, \mathrm{CC}$ & 42 & - & 42 \\
\hline $4-1$ & 37 & - & 37 \\
\hline $4-2$ & 56 & - & 56 \\
\hline $4, C C$ & 37 & - & 37 \\
\hline $5-1$ & 21 & - & 21 \\
\hline $6-1$ & \multicolumn{3}{|c|}{$\begin{array}{l}\text { Too few Radiolaria } \\
\text { for determination }\end{array}$} \\
\hline $6, \mathrm{CC}$ & & $\begin{array}{l}\text { Too few Radiolaria } \\
\text { for determination }\end{array}$ & \\
\hline
\end{tabular}

intensities whereas, in general, spyrids continue to concentrate preferentially at higher intensities. Alternatively, the cores immediately above the peak may have suffered a degree of solution higher than that to have affected any other segment of the column.

\section{"SOLUTION SEGMENTS" AT SITE 289}

Very tentatively in Figure 1 we have indicated the segments at Site 289 which could be interpreted as showing more or less well-defined effects of solution relative to immediately adjacent segments. For convenience, the "solution segments" are numbered downwards S1-S8 and "graded" A or B according to the degree of certainty with which they can be defined. The A grade is used only for the three segments, two very thin, where there is reinforcement of the spyrid and/or collosphaerid evidence by all three other lines of evidence which have been considered.
Below Core 289-99 the evidence is equivocal. The change of profile between Cores 289-105 and 289-104 is almost certainly due to the virtual extinction at this level of Thyrsocyrtis species, distinctly robust and probably solution-resistant forms which would tend to mask any spyrid concentration at lower levels.

Moore (1969) experimentally determined the relative solution resistances of 40 Radiolaria species ranging in age from early Eocene to Holocene. Species were ranked in 10 groups which can be referred to by number from (1) most soluble to (10) least soluble. Some independent justification for our use of total spyrid count as a crude indicator of degree of dissolution emerges from these experimental results in that seven of the eight spyrid species considered by Moore fall within the five most resistant groups (6) to (10), and five of these species belong to the three most resistant groups (8) to (10).

Species which show some decline in frequency within our supposed "solution segments" can be detected in the tabulation of Site 289 Radiolaria (Holdsworth, this volume, table 5). The species showing the more obvious declines within segments are listed below, together with the number of their experimentally determined solubility grouping, where known:

\section{S2B Ommatartus tetrathalmus (3) \\ S3A Ommatartus penultimus (5) \\ Ommatartus avitus \\ Lithopera bacca \\ S7A Lithocyclia angusta (4) \\ Cannartus prismaticus (6) \\ Theocyrtis annosa Form A (7)}

Contrary to expectation, these species show a broad spread of experimental solution value, though it should be noted that forms of $C$. prismaticus and $T$. annosa which decline in S7A are both early morphotypes, considerably less robust than their descendants. The most obvious discrepancy between the experimental results and observed distribution at Site 289 relates to Spongaster tetras, rated very soluble-(2)-by Moore, but showing no obvious decline in S1B and S2B. A possible slight reduction of abundance of Stichocorys peregrina (4) may occur in S2B and S3A, but Stichocorys delmontensis (5) does not decline noticeably in S4B and S5B. Stichocorys species, however, merit closer attention as solution indicators (as may some Eucyrtidium species), for the completeness of preservation of individuals does seem to vary from level to level in 289 and may be more significant than abundance.

The positions of "solution segments" relative to Radiolaria zones at Site $\mathbf{2 8 9}$ are indicated in Holdsworth (this volume, table 5).

\section{CAUSE AND GEOLOGIC SIGNIFICANCE OF VARIATION IN RADIOLARIA DISSOLUTION}

The geologic interpretation of variations in Radiolaria dissolution is complicated. Several factors have been considered by authors as influencing the abundance and preservation of radiolarians in surface sediments. Attempts to interpret vertical fluctuations within a single hole are complicated further by the possibility of influence by late diagenetic processes and progressive 
aging of the sediments. In 289 , however, there is a wide range of age of apparent "solution segments" in consistently very carbonate-rich sediments so that neither aging nor vertical variation in intrastrata dissolution satisfactorily explains the pattern. The apparent rather constant bulk composition of the column also leads us to discount clay-mineral content as an important control on dissolution (see Goll and Bjorklund, 1974), though very little data on clay distribution at Site 289 are available.

It does seem likely, however, that the factors which governed solution differences between the two sites studied were also important in determining the vertical fluctuations in dissolution tentatively identified in the 289 column. Thus, some clue to the general controls on Radiolaria dissolution in the Ontong-Java area might be expected to lie in other geologic contrasts between Sites 288 and 289.

Obvious differences between sites are: (1) the greater present-day water depth of 288; (2) the greater degree of chertification of the Site 288 Oligocene; (3) the considerably heavier contamination of Site 288 sediments by upwardly reworked foraminifera, nannoplankton, and Radiolaria_particularly evident at certain horizons (see Biostratigraphic Summary, Site 288, this volume); (4) the presence within the post-Eocene 288 succession of probably at least five stratigraphic discontinuities (see Biostratigraphic Summary, Site 288 , this volume) none of which are developed at Site 289.

The greater water depth per se at Site 288 is unlikely to have significantly increased opal dissolution. Berger (1968) demonstrated a reduction in Radiolaria solution rate with increasing depth. Johnson (in press) found evidence for slightly better preservation of Pleistocene Radiolaria at deeper water sites in the eastern Pacific, though the circumstances may differ significantly from those of the 288-289 situation (see below).

Absence or scarcity of Radiolaria in heavily chertified carbonate sediments is comparatively common, and it is generally assumed that the bulk of chert silica is of radiolarian origin. At Site 288 , however, marked chertification-though evident in younger sediments than at Site 289-does not extend to the Miocene where dissolution contrasts with 289 are particularly marked.

More significant may be the reworked fossils of 288 and the stratigraphic discontinuities. Both suggest that the plateau margin was subject to somewhat more intense Cenozoic bottom current activity than the plateau surface, and it seems possible that differences in intensity of current activity may explain both vertical and lateral variations in dissolution.

Johnson (in press) has shown that comparatively young (Pleistocene) fossil Radiolaria assemblages dissolve readily in a stream of seawater and that degree of solution is proportional to the time of exposure to the water stream. Solution of previously unfossilized tests, before appreciable adsorption of metallic cations (Lewin, 1961; Goll and Bjorklund, 1974) would probably be more rapid still. Thus, any factor slightly delaying the burial of a Radiolaria skeleton and lengthening the period of its contact with free seawater will significantly increase the chance of its dissolution.
Slight intensification of sediment-surface reworking due to turbulence associated with relative increase in current velocity is likely to be one such factor. Increase in the length of preburial transport of Radiolaria tests during periods of higher current velocity could have had an equally potent influence on dissolution.

The higher degree of dissolution of assemblages at Site 288 is possibly due in part to greater turbulence at the site induced by currents accelerated down the marginal slopes of the plateau; in part to contributions of relatively far-traveled, solution-resistant, skeletons from the plateau surface and of resistant tests reworked from the unstable deposits of the plateau slopes. Some parallel is suggested with the situation found in the Panama Basin where radiolarian-rich sediments are due to winnowing of tests from submarine highs (Moore et al., 1973; Kowsmann, 1973) and redeposition of skeletons in the shallower portions of adjacent basins (2-3000 $\mathrm{m})$, the transported assemblages showing poorer preservation than the wholly autochthonous assemblages of the ridge crests (Dinkleman, quoted in Kowsmann 1973). We are inclined to attribute the apparent vertical fluctuations in dissolution intensity at Site 289 to relatively slight fluctuations in the velocity of currents sweeping the plateau surface subsequent to the last major current episode which must be postulated to explain the Eocene/Oligocene discontinuity. The tentatively identified "solution segments" at Site 289 show no significant contamination by clearly older radiolarians. In this area of very high productivity and low relief, late Oligocene and younger currents were incompetent to rework radiolarians from any but the uppermost sediment layers.

The deeper water Site 288 has been interpreted as an area of greater turbulence, inducing greater selective solution of Radiolaria assemblages contributed from the overlying water column and, at the same time, acting as a repository for far-traveled and therefore "leached" assemblages. In contrast, Johnson (in press) noted a slightly lesser degree of selective solution in Pleistocene Radiolaria assemblages at his deeper water eastern Pacific sites. He also envisaged downslope transport of siliceous microfossils with opal enrichment of the deeper water sediments and consequent increase in "buffering" against opal dissolution during diagenesis. At the eastern Pacific sites, the Radiolaria assemblages enriching the deeper water sediments seem not to have suffered appreciable selective solution during transport, perhaps due to less prolonged transport in an area of generally weaker current activity (Johnson in press).

Several authors have noted that the abundance of radiolarians in surface sediments is closely correlatable and directly proportional with the productivity of the overlying water mass. Johnson (in press) found a further correlation between productivity and preservation in that selective dissolution of fossil Radiolaria assemblages is at a minimum in relatively richly radiolarian sediments beneath highly productive water masses. At Site 289 , therefore, fluctuations in opal productivity with time could provide an alternative explanation of the apparent "solution segments," although it seems highly unlikely that productivity differences were 
responsible for the dissolution contrasts observed between Sites 289 and 288 .

Two lines of argument, neither conclusive, slightly favor the view that current activity rather than productivity was the main control over Radiolaria dissolution at Site 289. Firstly, the late Eocene through Pliocene column of biogenous sediment, very little contaminated with nonbiogenic components, is unusually thick and would seem to imply a uniformly high general productivity at a site of invariant, essentially equatorial position.

Secondly, slight indications exist that some periods of intensified Radiolaria dissolution on the plateau surface were periods of nondeposition and/or erosion at the plateau margin (288). Such a relationship might be expected if degree of dissolution increased with increase in current activity and, as has been suggested, the effects of current activity were proportionally greater at the marginal site.

At Site 288, sediments equivalent to "solution segments" S2B and S3A are probably wholly or partly cut out by the major late Pliocene/late Miocene discontinuity between 288-5, CC and 288-6-1. The probable middle Miocene/latest Oligocene discontinuity between 288-11 and 288A-1-1 could cut out sediments equivalent to the upper half of S5B, but also may cut out the equivalents of immediately higher 289 cores which show no signs of increased Radiolaria dissolution. A rather precise coincidence may exist between S8A and a discontinuity inferred between 288A-4, CC and 288A-5-1 (Holdsworth, this volume). The relationship between plateau surface "solution segments" and plateau margin discontinuities is far from being convincing, however.

\section{BIOSTRATIGRAPHIC SIGNIFICANCE OF RADIOLARIA DISSOLUTION}

Comparatively gross upward reworking and associated dissolution of Radiolaria assemblages of the type discussed by Moore (1969) is unlikely to go undetected. The more subtle effects of slight dissolution fluctuations, suspected at 289 , may be more difficult to identify yet have a significant influence on the levels, spacings, and sequence of Radiolaria "events" as determined in different boreholes. As dissolution increases, the detectability of comparatively common, solution-resistant forms will be unchanged, but the abundances of rare and/or more soluble fossil species may fall below the level of detection while the frequencies of otherwise very rare, resistant forms may be raised to a level at which detection is possible. Determined limits of fossil range may in some instances more closely mirror the dissolution flux than the evolutionary change within the contemporaneous plankton. If increased dissolution is a consequence of intensified current activity, further complications could be introduced by associated slight upward reworking of more resistant fossils.

The ability of such effects to distort the fossil reflection of living population change is probably reduced to a minimum at Site 289 by the abnormally high accumulation rate, In more slowly accumulated columns there may well be stronger distortions. Before differences in sequence of fossil events observed in different boreholes (Sanfilippo and Riedel, 1974) are taken as reliable indications of the diachraneity of biological events, it seems necessary to closely examine the opal dissolution histories of the columns concerned.

\section{ACKNOWLEDGMENTS}

The senior author has benefited from discussion with Robert Goll, Stanley Kling, William Riedel, Annika Sanfilippo, and Jean Westburg and from correspondence with Thomas Johnson. The junior author gratefully acknowledges a grant in support of her work from the University of Keele.

\section{REFERENCES}

Berger, W.H., 1968. Radiolarian skeletons: solution at depths: Science, v. 159, p. 1237-1238.

Goll, R. and Bjorklund, K.R., 1974. Radiolaria in surface sediments of the South Atlantic: Micropaleontology, v. 20, p. 38-75.

Johnson, T.C., in press. The dissolution of siliceous microfossils in surface sediments of the Eastern tropical Pacific: Deep-Sea Res.

Kowsman, R.O., 1973. Coarse components in surface sediments of the Panama Basin, Eastern Equatorial Pacific: J. Geol., v. 81 , p. $473-494$.

Lewin, T.C., 1961. The dissolution of silica from diatom walls: Geochim. Cosmochim. Acta, v. 21, p. 182-198.

Moore, T.C., Jr., 1969. Radiolaria: change in skeletal weight and resistance to solution: Geol. Soc. Am. Bull., v. 80, p. 2103-2108.

Moore, T.C., Jr., Heath, G.R., and Kowsmann, R.O., 1973. Biogenic sediments of the Panama Basin: J. Geol., v. 81. p. 458-472.

Sanfilippo, A. and Riedel, W.R., 1974. Radiolaria from the west-central Indian Ocean and Arabian Sea. In Initial Reports of the Deep Sea Drilling Project, Volume 24: Washington (U.S. Government Printing Office) p. 997. 1036. 


\section{PLATE 1}

Spyrid and/or collosphaerid concentrations at Site 288 .

All figures $\times 30$.

Figure $1 \quad 288-6-1,110-112 \mathrm{~cm} \mathrm{R}(\mathrm{a})$.

Spyrids $23 \%$, collosphaerids $36 \%$, Total $59 \%$.

Figure 2

288-9, CC R(a).

Spyrids $47 \%$, collosphaerids $31 \%$, total $78 \%$.

Figure 3

288A-1-3, 104-107 cm R.

Spyrids $73 \%$.

Figure $4 \quad 288-\mathrm{A}-4-2,92-94 \mathrm{~cm} \mathrm{R}(\mathrm{a})$.

Spyrids $56 \%$. 
PLATE 1
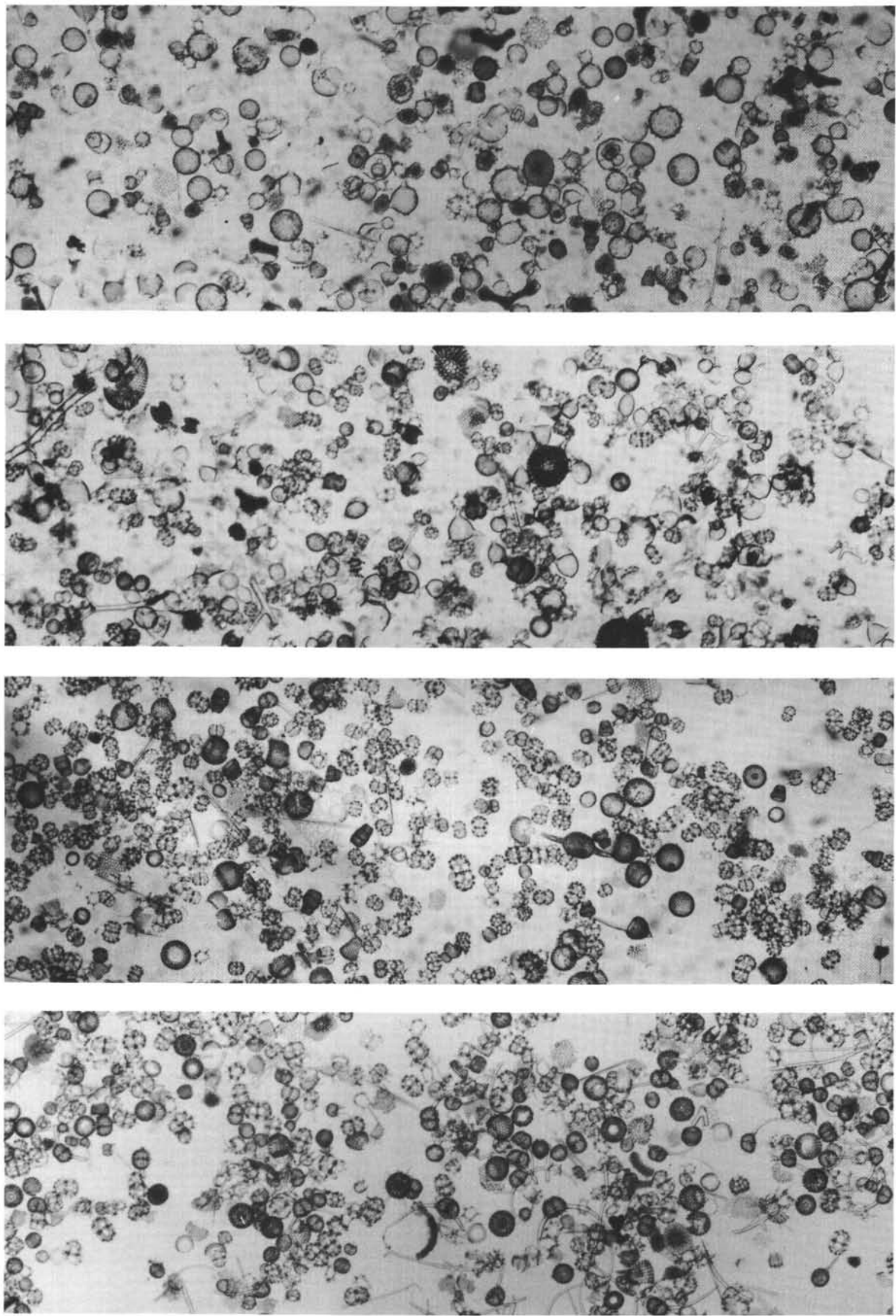